\title{
COMPARISON OF BUFFERS FOR EXTRACTION OF MITE ALLERGEN DER P 1 FROM DUST
}

\author{
Ljerka PRESTER, Jelena KOVAČIĆ, and Jelena MACAN \\ Institute for Medical Research and Occupational Health Zagreb, Croatia \\ Received in February 2012 \\ CrossChecked in February 2012 \\ Accepted in August 2012
}

\begin{abstract}
Der $\mathrm{p} 1$ is the main allergen of house dust mite Dermatophagoides pteronyssinus, which has routinely been detected in residential dust. However, the procedure for extracting Der $\mathrm{p} 1$ from reservoir dust has not been well defined. The aim of this study was to compare Der $\mathrm{p} 1$ mass fractions in dust extracts prepared using the following extraction buffers: phosphate ( $\mathrm{pH} \mathrm{7.4),} \mathrm{borate} \mathrm{(} \mathrm{pH} 8.0$ ), and ammonium bicarbonate $(\mathrm{pH} 8.0)$, all with $0.05 \%$ Tween 20 . Twenty-eight dust samples were divided into three aliquots and each portion was extracted with one of the three buffers at room temperature. Der $\mathrm{p} 1$ mass fractions were measured in a total of 84 dust extracts using the enzyme immunoassay (range: $0.1 \mu \mathrm{g} \mathrm{g}^{-1}$ to $7.53 \mu \mathrm{g} \mathrm{g}^{-1}$ ). Statistical methods including intraclass correlation showed a high agreement between Der $\mathrm{p} 1$ mass fractions irrespective of the extracting medium. Our results suggest that all three buffers are suitable for the extraction of mite allergens and routine Der $\mathrm{p} 1$ analysis in dust.
\end{abstract}

KEY WORDS: Dermatophagoides pteronyssinus, ELISA, extraction buffers, indoor allergens, intraclass correlation, settled dust

House dust mites are the source of 21 allergens identified so far. The major allergens of the common dust mite (Dermatophagoides pteronyssinus) are Der $\mathrm{p} 1$ and Der $\mathrm{p} 2$ (1-3). Exposure to these allergens is associated with allergic symptoms and asthma in sensitised people (1-3). Reservoir dust samples have been used as a proxy for Der $p 1$ exposure in residential $(1,4)$ and occupational $(5)$ settings. In order to compare results from different studies investigating allergen exposure and related health effects, both the collection techniques and laboratory protocols (analysis, extraction, and storage) should be comparable. Enzyme-linked immunosorbent assay (ELISA) is the standard method for quantification of common indoor allergens in reservoir dust (6). However, there is no standard protocol for the extraction of allergens from dust (7). Several solutions have regularly been used for extraction of Der $\mathrm{p} 1$ in laboratories worldwide including phosphate, borate, and ammonium bicarbonate buffers (Table 1). Some laboratories add the non-ionic surfactant Tween 20 to the extraction medium and some do not. Little information is available about the extraction efficiency of buffers on Der $p 1$ measurements. Siebers et al. (8) found that the type of buffer affected measurement of Der $p 1$ levels. In this short report, Der $p 1$ concentrations (high exposure level) in a borate extract were much higher than in phosphate and ammonium bicarbonate extracts. However, other operating conditions (such as time and temperature) appeared to be very important for Der $p 1$ extraction and Der p 1 measurement with ELISA. Extraction at a lower temperature $\left(4^{\circ} \mathrm{C}\right)$ resulted in lower Der $\mathrm{p} 1$ level, irrespective of the buffer type. This lack of standardised operating conditions, certainly contributes to great inter-laboratory differences in Der p 1 measurements $(7,9)$. 
The aim of our study was to establish correlations between Der $\mathrm{p} 1$ mass fractions in dust samples extracted with three common buffers, namely phosphate, borate, and ammonium bicarbonate, all containing $0.05 \%$ Tween 20 , at room temperature.

\section{MATERIALS AND METHODS}

\section{Dust collection}

Twenty-eight dust samples were collected from 18 urban households in Zagreb, Croatia between 2007 and 2009. Samples were taken by vacuuming a carpeted area of the living rooms using a standard vacuum cleaner adapter and cellulose filter (Heska AG, Freiburg, Switzerland) as described earlier (10).

\section{Dust extraction and analysis}

Three buffers were used for Der $\mathrm{p} 1$ extraction from settled dust: phosphate (PBS; $\mathrm{pH} 7.4)$, borate (BBS; pH 8.0; Titrisol, Merck, Germany), and $0.125 \mathrm{~mol} \mathrm{~L}^{-1}$ ammonium bicarbonate (ABS; pH 8.0; Kemika, Zagreb). The final concentrations of the PBS components were $137 \mathrm{mmol} \mathrm{L}^{-1}$ for $\mathrm{NaCl}, 10 \mathrm{mmol}$ $\mathrm{L}^{-1}$ for $\mathrm{Na}_{2} \mathrm{HPO}_{4} \times 2 \mathrm{H}_{2} \mathrm{O}, 2 \mathrm{mmol} \mathrm{L}^{-1}$ for $\mathrm{KH}_{2} \mathrm{PO}_{4}$, and $2.7 \mathrm{mmol} \mathrm{L}^{-1}$ for $\mathrm{KCl}$. According to the manufacturer (Merck, Germany), the borate buffer consisted of $0.11 \mathrm{~mol} \mathrm{~L}^{-1} \mathrm{H}_{3} \mathrm{BO}_{3}, 0.044 \mathrm{~mol} \mathrm{~L}^{-1} \mathrm{HCl}$, and $0.056 \mathrm{~mol} \mathrm{~L}^{-1} \mathrm{NaOH}$. All buffers contained $0.05 \%$

Table 1 Summary of reported buffers and operating conditions for extraction of Der $p 1$ and other indoor allergens from dust

\begin{tabular}{|c|c|c|}
\hline Extraction buffer & Tween 20 & Reference \\
\hline \multicolumn{3}{|l|}{ Phosphate (PBS) pH 7.4} \\
\hline $\mathrm{PBS}^{\mathrm{a}}$ & 1 & 23,24 \\
\hline PBS (30 min, RT) & 0.05 & 20,25 \\
\hline $\operatorname{PBS}\left(1 \mathrm{~h}, 30^{\circ} \mathrm{C}\right)$ & 0.05 & 26 \\
\hline PBS (2 h, RT) & 0.05 & 27,28 , this work \\
\hline PBS-1 \% BSA $(2 \mathrm{~h}, \mathrm{RT})$ & 0.05 & 29 \\
\hline PBS-1 \% BSA (overnight, RT) & 0.5 & 30 \\
\hline PBS- $0.2 \%$ BSA (overnight, $4{ }^{\circ} \mathrm{C}$ ) & 0.2 & 31 \\
\hline \multicolumn{3}{|l|}{ Borate (BBS) $\mathrm{pH} 8.0$} \\
\hline $\mathrm{BBS}^{\mathrm{a}}$ & / & $13,32-35$ \\
\hline BBS (2 h, RT) & 0.05 & this work \\
\hline BBS-5 \% BSA ${ }^{\mathrm{a}}$ & I & 36 \\
\hline BBS-5 \% BSA (overnight, $4{ }^{\circ} \mathrm{C}$ ) & 1 & 37 \\
\hline BBS-aprotinin $\left(2 \mathrm{~h}, 4^{\circ} \mathrm{C}\right)$ & 0.1 & 38 \\
\hline \multicolumn{3}{|l|}{ Ammonium bicarbonate (ABS) $\mathrm{pH} 8.0$} \\
\hline $\operatorname{ABS}(2 \mathrm{~h}, \mathrm{RT})$ & 1 & 39 \\
\hline $\operatorname{ABS}(2 \mathrm{~h}, \mathrm{RT})$ & 0.05 & 21 , this work \\
\hline
\end{tabular}

\section{$R T$ - room temperature}

$B S A$ - bovine serum albumin

- extraction conditions not available

Table 2 Der $p 1$ findings $\left(\mu g g^{-1}\right)$ by extraction medium at two exposure levels

\begin{tabular}{lcccc}
\hline Der p 1 & Median & Mean \pm SD & Range & n \\
\hline low level & \multicolumn{3}{c}{0.12 to 1.655} & 18 \\
\hline PBS-T & 0.648 & $0.721 \pm 0.53$ & 0.105 to 1.62 & 18 \\
\hline BBS-T & 0.753 & $0.696 \pm 0.497$ & 0.060 to 1.565 & 18 \\
\hline ABS-T & 0.645 & $0.616 \pm 0.462$ & & 10 \\
\hline moderate level & & & 2.015 to 7.255 & 10 \\
\hline PBS-T & 3.620 & $3.774 \pm 1.681$ & 2.075 to 7.42 & 10 \\
\hline BBS-T & 3.605 & $3.958 \pm 1.685$ & 2.270 to 7.525 & \\
\hline ABS-T & 3.422 & $3.838 \pm 1.667$ & & \\
\hline
\end{tabular}

PBS-T - phosphate buffer-Tween

$B B S-T$ - borate buffer-Tween

ABS-T-ammonium bicarbonate buffer-Tween 

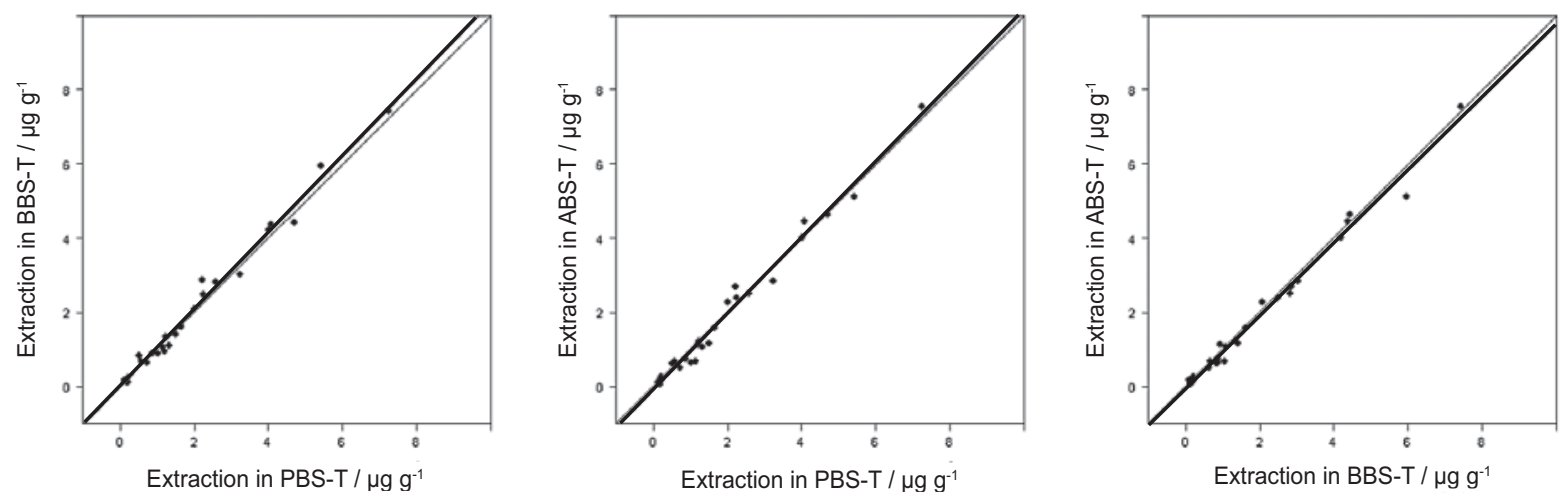

- identity line

- linear regression line

Figure 1 Linear regression analysis for different pairs of extraction solutions

Tween 20 (T) (Merck, Germany). Before extraction, each sample was manually sieved through a $300 \mu \mathrm{m}$ sieve, mixed until homogenous, and weighed. Fine dust samples were divided into three 100-mg aliquots, and $2 \mathrm{~mL}$ of extraction solution was added to each aliquot. Extractions were done at room temperature with constant shaking on a Vortex mixer (Ika Vortex, Germany) for $2 \mathrm{~h}$. After $10 \mathrm{~min}$ of centrifugation at $1,000 \mathrm{xg}$, supernatants were stored in plastic tubes at $-20{ }^{\circ} \mathrm{C}$ until analysis for Der $\mathrm{p} 1$ content. A total of 84 dust extracts were analysed for Der $p 1$ content.

The mass fractions of Der $p 1$ were determined with capture ELISA, using a commercial kit (Indoor Biotechnologies Ltd, Cardiff, UK) as described in our earlier article (10). The kit contained monoclonal antibody 5H8 (mouse anti-Derp 1, IgG2A) (lot number 30034) as capture antibody, biotinylated monoclonal antibody 4C1 (mouse IgG1; lot number 30068) as secondary antibody, and Der $\mathrm{p} 1$ standard (2500 ng $\mathrm{mL}^{-1}$ ). All antibodies (except capture $\mathrm{mAb}$ ), standards, dust extracts, and positive and negative controls were diluted in PBS-T containing $1 \%$ bovine serum albumin (BSA; PBS-T-BSA; Sigma, USA). Dust extracts were diluted three or six times depending on the Der $\mathrm{p} 1$ level. Aliquots of extracts were placed into a 96-well microtitre plate (Maxi Sorp, Nunc, Denmarkt) following the manufacturer's instructions. After all reagent incubations, optical densities were read at $450 \mathrm{~nm}$ using a microtitre plate ELISA reader (IASON, Vienna, Austria). The limit of detection was $0.1 \mu \mathrm{g} \mathrm{g}^{-1}$. The intra-assay coefficient of variation $(\mathrm{CV})$ and inter-assay CV for Der $\mathrm{p} 1$ ELISA were $6.9 \%$ and $13.1 \%$, respectively (10).

\section{Statistical analysis}

All data were analysed using free statistical software R, version 2.13.2. Descriptive statistics was used to illustrate the distribution of Der $p 1$ in PBS-T, BBS-T, and ABS-T extracts. According to allergen mass fraction, Der $p 1$ values were grouped in low (from $0.1 \mu \mathrm{g} \mathrm{g}^{-1}$ to $2.0 \mu \mathrm{g} \mathrm{g}^{-1}$ ) and moderate (from $2.01 \mu \mathrm{g} \mathrm{g}^{-1}$ to $\left.7.53 \mu \mathrm{g} \mathrm{g}^{-1}\right)$ levels. Der $\mathrm{p} 1$ measurements were compared for each pair of buffers and, in a separate procedure, for all three buffers. For each pair of buffers, Der $\mathrm{p} 1$ measurements were compared using correlation coefficients (Pearson's and Spearman's), and linear regression coefficients (slope and intercept, with $95 \%$ confidence intervals, $95 \%$ CI) in two mass ranges. The agreement between Der $p 1$ values for each pair of buffers was estimated using the intraclass correlation coefficient (ICC) (11, 12). This coefficient was also used to determine the agreement between Der $p 1$ values in all three buffers, since other coefficients allow only paired measurements.

Intraclass correlation coefficients were calculated from two-way random effects model with both buffers and dust batches as covariates (11) using R software. Intraclass coefficient represents the proportion of data variation that can be explained by between-class variability (variability in Der $\mathrm{p} 1$ values between batches). All coefficients were calculated with their $95 \%$ confidence intervals. The level of significance was set at 0.05 . 
Table 3 Regression analysis (slopes, intercept with $95 \%$ confidence interval) and correlation coefficients (Pearson's, Spearman's and intraclass) for Der $p 1$ mass fractions in PBS-T, PBS-T, and ABS-T extracts

\begin{tabular}{|c|c|c|c|c|c|c|}
\hline \multirow[b]{2}{*}{$\begin{array}{l}\text { Extraction } \\
\text { comparison }\end{array}$} & \multirow{2}{*}{$\begin{array}{c}\text { Der p } 1 \\
\text { range / } \\
\mu g g^{-1}\end{array}$} & \multicolumn{2}{|c|}{ Linear regression } & \multicolumn{2}{|c|}{ Correlation } & \multirow[b]{2}{*}{$\begin{array}{c}\text { ICC } \\
(95 \% \mathrm{CI})\end{array}$} \\
\hline & & $\begin{array}{c}\text { Slope } \\
(95 \% \text { CI) }\end{array}$ & $\begin{array}{l}\text { Intercept } \\
\text { (95\% CI) }\end{array}$ & $\begin{array}{c}\text { Pearson } \\
(95 \% \text { CI })\end{array}$ & Spearman & \\
\hline \multirow{3}{*}{$\begin{array}{l}\text { PBS-T vs. } \\
\text { BBS-T }\end{array}$} & 0.1 to 2.0 & $\begin{array}{c}0.906 \\
(0.779,1.032) \\
\end{array}$ & $\begin{array}{c}0.043 \\
(-0.07,0.155)\end{array}$ & $\begin{array}{c}0.967 \\
(0.912,0.988)\end{array}$ & 0.931 & $\begin{array}{c}0.966 \\
(0.912,0.987)\end{array}$ \\
\hline & 2.01 to 7.53 & $\begin{array}{c}0.988 \\
(0.849,1.126)\end{array}$ & $\begin{array}{c}0.23 \\
(-0.338,0.798)\end{array}$ & $\begin{array}{c}0.985 \\
(0.938,0.997)\end{array}$ & 0.964 & $\begin{array}{c}0.981 \\
(0.909,0.995)\end{array}$ \\
\hline & overall & $\begin{array}{c}1.037 \\
(0.991,1.084) \\
\end{array}$ & $\begin{array}{c}-0.018 \\
(-0.137,0.101)\end{array}$ & $\begin{array}{c}0.994 \\
(0.986,0.997)\end{array}$ & 0.980 & $\begin{array}{c}0.993 \\
(0.985,0.997)\end{array}$ \\
\hline \multirow{3}{*}{$\begin{array}{l}\text { PBS-T vs. } \\
\text { ABS-T }\end{array}$} & 0.1 to 2.0 & $\begin{array}{c}0.833 \\
(0.695,0.971) \\
\end{array}$ & $\begin{array}{c}0.015 \\
(-0.107,0.138) \\
\end{array}$ & $\begin{array}{c}0.954 \\
(0.879,0.983)\end{array}$ & 0.946 & $\begin{array}{c}0.927 \\
(0.753,0.975)\end{array}$ \\
\hline & 2.01 to 7.53 & $\begin{array}{c}0.977 \\
(0.84,1.115)\end{array}$ & $\begin{array}{c}0.15 \\
(-0.413,0.714)\end{array}$ & $\begin{array}{c}0.985 \\
(0.937,0.997)\end{array}$ & 0.964 & $\begin{array}{c}0.986 \\
(0.948,0.996)\end{array}$ \\
\hline & overall & $\begin{array}{c}1.022 \\
(0.973,1.071)\end{array}$ & $\begin{array}{c}-0.084 \\
(-0.209,0.041)\end{array}$ & $\begin{array}{c}0.993 \\
(0.985,0.997)\end{array}$ & 0.984 & $\begin{array}{c}0.993 \\
(0.984,0.997)\end{array}$ \\
\hline \multirow{3}{*}{$\begin{array}{l}\text { BBS-T vs. } \\
\text { ABS-T }\end{array}$} & 0.1 to 2.0 & $\begin{array}{c}0.9 \\
(0.772,1.027) \\
\end{array}$ & $\begin{array}{c}-0.011 \\
(-0.118,0.097) \\
\end{array}$ & $\begin{array}{c}0.966 \\
(0.91,0.988) \\
\end{array}$ & 0.933 & $\begin{array}{c}0.952 \\
(0.836,0.984)\end{array}$ \\
\hline & 2.01 to 7.53 & $\begin{array}{c}0.972 \\
(0.823,1.121)\end{array}$ & $\begin{array}{c}-0.01 \\
(-0.646,0.625)\end{array}$ & $\begin{array}{c}0.983 \\
(0.927,0.996)\end{array}$ & 1 & $\begin{array}{c}0.982 \\
(0.933,0.995)\end{array}$ \\
\hline & overall & $\begin{array}{c}0.98 \\
(0.937,1.023)\end{array}$ & $\begin{array}{c}-0.057 \\
(-0.171,0.057)\end{array}$ & $\begin{array}{c}0.994 \\
(0.987,0.997)\end{array}$ & 0.982 & $\begin{array}{c}0.993 \\
(0.983,0.997)\end{array}$ \\
\hline
\end{tabular}

PBS-T - phosphate buffer-Tween

$B B S-T$ - borate buffer-Tween,

ABS-T - ammonium bicarbonate buffer-Tween,

ICC - intraclass correlation coefficient

All correlation coefficients and regression slopes significantly differed from zero $(p<0.001)$

\section{RESULTS}

Table 2 shows medians, means, and ranges of Der $\mathrm{p} 1$ mass fractions in dust extracts. Table 3 shows the results of the statistical analysis. Respective Pearson's correlation coefficients between Der $\mathrm{p} 1$ mass fractions in PBS-T $v s$. BBS-T, PBS-T vs. ABS$\mathrm{T}$, and BBS-T $v s$. ABS-T extracts were 0.967, 0.954, and 0.966 for low exposure range $\left(0.1 \mu \mathrm{g} \mathrm{g}^{-1}\right.$ to $2 \mu \mathrm{g}$ $\left.\mathrm{g}^{-1}\right)$ and $0.985,0.985$, and 0.983 for moderate exposure range $\left(2.01 \mu \mathrm{g} \mathrm{g}^{-1}\right.$ to $\left.7.53 \mu \mathrm{g} \mathrm{g}^{-1}\right)$. Spearman's correlation coefficients between Der $\mathrm{p} 1$ mass fractions in the extraction buffers and exposure levels ranged from 0.931 to 1 , while intraclass correlation coefficients ranged from 0.927 to 0.993 , showing a statistically significant and high agreement in both level ranges. The lowest agreement was observed for Der $\mathrm{p} 1$ measurements in PBS-T and ABS-T extracts (ICC and Pearson's coefficient of 0.927 and 0.954 , respectively) for low exposure range. In the moderate allergen level group, ICC ranged from 0.981 to 0.986 between all three extraction buffers (without significant differences between coefficients), suggesting very good agreements between Der $\mathrm{p} 1$ measurement. Table 3 also shows linear regression coefficients (slope, intercept, and $95 \%$ confidence intervals) for each pair of extraction buffers. Figure 1 shows a very good agreement between Der $p 1$ measurements between pairs of buffers obtained with linear regression. Each plot shows both the identity line and regression line. The identity line was not included in the $95 \%$ confidence interval for linear regression parameters only in the case of Der $\mathrm{p} 1$ measurements in PBS-T and ABS-T extracts that contained low allergen level.

The agreement between all three extraction buffers estimated with ICC was 0.949 (95\% CI: $0.881,0.98$ ) for low exposure range, 0.983 (95\% CI: 0.952, 0.995 ) for moderate exposure range, and $0.993(95 \% \mathrm{CI}$ : $0.986,0.996)$ overall. 


\section{DISCUSSION}

A number of studies have measured Der $p 1$ in settled dust worldwide in order to assess exposure risk, especially in children and adults with asthma (4, 13). Monitoring household allergens may play an important role in asthma control (14), but it needs standardised and harmonised protocols for indoor allergen sampling and measurement. Our results show a high correlation and agreement between Der $\mathrm{p} 1$ measurements in PBS-T, BBS-T, and ABS-T at either low or moderate allergen levels. Furthermore, overall ICCs for Der $\mathrm{p} 1$ measurements are high (0.993) for all three buffers. ICC values were slightly lower for the low exposure range than for the moderate because the latter range is wider and involves greater betweenclass variability and, consequently, a higher intraclass coefficient. Regression analysis showed the slope very close to 1 and small y-axis intercept for each pair of extraction data (Table 3, Figure 1). This reflects high homogeneity of Der 1 values and excellent agreement between measurements for each pair of extraction buffers (PBS-T, BBS-T, and ABS-T) and may help in standardising the extraction procedure.

Similarly, Martin et al. (15) found no buffer effect on the extraction of Fel d 1 (cat allergen) from dust. Pate et al. (7) also observed that the extraction step was not a significant source of variability. In contrast, Siebers et al. (8) found that borate buffer was superior to PBS and ABS. However, they did not use Tween 20 in that study and their results are not fully comparable with ours. Several investigators reported that adding Tween 20 (as a dispersing and solubilising agent) to the extraction media improved endotoxin detection in dust extracts (16-18). Furthermore, adding Tween 20 to pyrogen-free water has been recommended for endotoxin analysis by the European Committee for Standardization (CEN) (19). However, the influence of Tween 20 on allergen extraction efficiency has not been investigated or its use universally accepted. Therefore, further research should investigate the effect of Tween 20 on extraction efficiency of indoor allergens from dust.

However, variety between laboratories can be great in other operating conditions such as temperature and time of extraction (7). At a lower extraction temperature $\left(4{ }^{\circ} \mathrm{C}\right)$, Sieber et al. $(8)$ reported lower Der $\mathrm{p} 1$ level irrespective of the buffer type. Furthermore, dust sampling and storage may also affect laboratory performance $(20,21)$. According to Fahlbusch et al. (21), storing dust at $-20^{\circ} \mathrm{C}$ for up to 10 months had no effect on mite allergen levels but Fel d 1 concentration significantly dropped with storage time. However, the freeze-thaw effects on Der $\mathrm{p} 1$ concentrations in dust extracts or dust samples have not yet been investigated.

In 2005, Pate et al. (7) reported the results of the first quality control of common indoor allergen measurements (mite, cockroach, and pets) in residential dust. They found a strong inter-laboratory variability in the levels of all indoor allergens, which pointed to poor standardisation of some steps in allergen measurements. Harmonising protocols for indoor allergen measurement can make results more comparable and lower inter-laboratory variability. Recently, Filep et al. (22) have developed a single standard for eight common indoor allergens. Adding a such control sample with declared allergen levels can improve performance and reduce variability between laboratories.

In this study the efficiency of buffers on Der $\mathrm{p} 1$ extraction from dust samples was compared using correlation coefficients (intraclass, Pearson's and Spearman's) and linear regression coefficients. Generally, intraclass correlation is a better indicator of agreement between different measurements than Pearson's and Spearman's correlation which may yield misleadingly higher values of agreement in case one extraction solution is constantly giving higher values than the other. Similarly, the linear regression model can produce regression line equal to the identity line even when data points are far from the estimated line. Another drawback of the regression model is the assumption that data points for at least one solution are free of measurement error, which is unrealistic in our case. However, we decided to include linear regression and Pearson's and Spearman's correlation coefficients as an addition to intraclass correlation to make possible a comparison with future studies.

\section{CONCLUSION}

Our results have shown excellent agreement between Der $\mathrm{p} 1$ measurements regardless of the extraction buffers (PBS-T, BBS-T, and ABS-T) or exposure level. Therefore, all three buffers plus $0.05 \%$ Tween 20 have proved equally efficient in the extraction of Der $\mathrm{p} 1$ from residential dust at room temperature. In order to harmonise extracting procedures, further studies should include extraction from samples with high Der $\mathrm{p} 1$ levels. In addition, 
further studies are necessary to find out if the results reported in this study can be generalised for other allergens in reservoir dust samples.

\section{Acknowledgement}

This study was supported by the Ministry of Science, Education and Sports of the Republic of Croatia (grant no. 022-0222411-2410).

\section{REFERENCES}

1. Wilson J, Dixon SL, Breysse P, Jacobs D, Adamkiewicz G, Chew GL, Dearborn D, Krieger J, Sandel M, Spanier A. Housing and allergens: A pooled analysis of nine US studies. Environ Res 2010;110:189-98.

2. Valero A, Serrano C. Are environmental controls effective for house-dust-mite allergies? Arch Bronconeumol 2004:40:389-91.

3. Custovic A, Taggart SC, Francis HC, Chapman MD, Woodcock A. Exposure to house dust mite allergens and the clinical activity of asthma. J Allergy Clin Immunol 1996;98:64-72.

4. Prester Lj. Arthropod allergens in urban homes. Arh Hig Rada Toksikol 2012;63(Suppl 1):47-56.

5. Macan J, Kanceljak-Macan B, Milković-Kraus S. Pyroglyphid mites as a source of work-related allergens. Arh Hig Rada Toksikol 2012;63(Suppl 1):57-66.

6. Luczynska CL, Arruda LK, Platts-Mills TAE, Miller JD, Lopez M, Chapman MD. A two-site monoclonal antibody ELISA for the quantification of the major Dermatophagoides spp. allergens, Der p 1 and Der p f 1. J Immunol Methods 1989;118:227-35.

7. Pate AD, Hamilton RG, Ashley PJ, Zeldin DC, Halsey JF. Proficiency testing of allergen measurements in residential dust. J Allergy Clin Imunol 2005; 116:844-50.

8. Siebers R, Luey B, Crane J, Fitzharris P. The effects of temperature and buffer on the extraction of Der $\mathrm{p} 1$ from dust. J Allergy Clin Immunol 1997;100:580.

9. Siebers R, Rains N, Fitzharris P, Crane J. The worldwide external Der $\mathrm{p} 1$ quality control program: results from round three. In: Siebers R, Fitzharris P, Cunningham M, Crane J, editors. Mites, asthma and domestic design III. Wellington: Wellington Asthma Research Group; 1997. p. 21-6.

10. Prester Lj, Brčić Karačonji I, Macan J. Determination of mite allergens in house dust using the enzyme immunoassay. Arh Hig Rada Toksikol 2007;58:413-9.

11. Shrout PE, Fleiss JL. Intraclass correlations: uses in assessing rater reliability. Psychol Bull 1979;86:420-8.

12. McGraw KO, Wong SP. Forming inferences about some intraclass correlation coefficients. Psychol Meth 1996;1:3046.

13. Zock JP, Heinrich J, Jarvis D, Verlato G, Norbäck D, Plana E, Sunyer J, Chinn S, Olivieri M, Soon A, Villani S, Ponzio M, Dahlman-Hoglund A, Svanes C, Luczynska C. Distribution and determinants of house dust mite allergens in Europe: The European Community Respiratory Health Survey II. J Allergy Clin Immunol 2006;118:682-90.
14. Baxi SN, Phipatanakul W. The role of allergen exposure and avoidance in asthma. Adolesc Med State Art Rev 2010;21:5771

15. Martin IR, Wickens K, Patchett K, Kent R, Fitzharris P, Siebers R, Lewis S, Crane J, Holbrook N, Town GI, Smith $\mathrm{S}$. Cat allergen levels in public places in New Zealand. NZ Med J 1998;111:356-8.

16. Douwes J, Versloot P, Hollander A, Heederik D, Doekes G. Influence of various dust sampling and extraction methods on the measurement of airborne endotoxin. Appl Environ Microbiol 1995;61:1763-9.

17. Spaan S, Doekes G, Heederik D, Thorne PS, Wouters IM. Effect of extraction and assay media on analysis of airborne endotoxin. Appl Environ Microbiol 2008;74:3804-11.

18. Liebers V, Raulf-Heimsoth M, Linsel G, Goldscheid N, Düser M, Stubel H, Brüning Th. Evaluation of quantification methods of occupational endotoxin exposure. J Toxicol Environ Health Part A 2007;70:1798-805.

19. CEN 2000. 14031. Workplace atmosphere: determination of airborne endotoxins. European Committee for Standardization, Brussels, Belgium.

20. Mason K, Crane J, Fitzharris P, Siebers R. The effect of sieving on Der $\mathrm{p} 1$ levels. Allergy 2001;56:1012-3.

21. Fahlbusch B, Koch A, Douwes J, Bischof W, Gehring U, Richter K, Wichmann HE, Heinrich J. The effect of storage on allergen and microbial agent levels in frozen house dust. Allergy 2003;58:150-3.

22. Filep S, Tsay A, Vailes L, Gadermaier G, Ferreira F, Matsui E, King EM, Chapman MD. A multi-allergen standard for the calibration of immunoassays: CREATE principles applied to eight purified allergens. Allergy 2012;67:235-41.

23. Raja S, Xu Y, Ferro AR, Jaques PA, Hopke PK. Resuspension of indoor aeroallergens and relationship to lung inflammation in asthmatic children. Environ Int 2010;36:8-14.

24. Arbes SJ, Sever M, Mehta J, Collette N, Thomas B, Zeldin DC. Exposure to indoor allergens in day-care facilities: Results from 2 North Carolina counties. J Allergy Clin Immunol 2005;116:133-9.

25. Nam HS, Siebers R, Lee SH, Park JS, Kim YB, Choi YJ, Lee $\mathrm{SH}$, Crane J. House dust mite allergens in domestic homes in Cheonan, Korea. Korean J Parasitol 2008;46:187-9.

26. Adhikari A, Lewis JS, Reponen T, DeGrasse EC, Grimsley LF, Chew GL, Iossifova Y, Grinshpun SA. Exposure matrices of endotoxin, (1ât'3)-Î_-D-glucan, fungi, and dust mite allergens in flood-affected homes of New Orleans. Sci Total Environ 2010;408:5489-98.

27. Earle CD, King EM, Tsay A, Pittman K, Saric B, Vailes L, Godbout R, Oliver KG, Chapman MD. High-throughput fluorescent multiplex array for indoor allergen exposure assessment. J Allergy Clin Immunol 2007;119:428-33.

28. Kim JL, Elfman L, NorbĂäck D. Respiratory symptoms, asthma and allergen levels in schools-comparison between Korea and Sweden. Indoor Air 2007;17:122-9.

29. Leung R, Lam CWK, Chan A, Lee M, Chan HIS, Pang SW, Lai CKW. Indoor environment of residential homes in Hong Kong-relevance to asthma and allergic disease. Clin Exp Allergy 1998;28:585-90.

30. Mitakakis TZ, Mahmic A, Educ GD, Tovey ER. Comparison of vacuuming procedures for reservoir dust mite allergen on carpeted floors. J Allergy Clin Immunol 2002;109:122-4.

31. Nishioka K, Yasueda H, Saito H. Preventive effect of bedding encasement with microfine fibres on mite sensitization. J Allergy Clin Immunol 1998;101:28-32. 
32. Kitch BT, Chew G, Burge HA, Muilenberg mL, Weiss ST, Platts-Mills TAE, O'Connor G, Gold DR. Socioeconomic predictors of high allergen levels in homes in the greater Boston area. Environ Health Perspect 2000;108:301-7.

33. Cohn RD, Arbes SJ, Jaramillo R, Reid LH, Zeldin DC. National prevalence and exposure risk for cockroach allergen in U.S. households. Environ Health Perspect 2006;114:522 6.

34. Stelmach I, Jerzynska J, Stelmach W, Majak P, Chew G, Gorski P, Kuna P. Cockroach allergy and exposure to cockroach allergen in Polish children with asthma. Allergy 2002;57:701-5.

35. Peters JL, Levy JI, Rogers CA, Burge HA, Spengler JD. Determinants of allergen concentrations in apartments of asthmatic children living in public housing. J Urban Health 2007;84:185-97.
36. Matsui EC, Wood RA, Rand C, Kanchanaraksa S, Swartz L, Curtin-Bronsan J, Eggleston PA. Cockroach allergen exposure and sensitization in suburban middle-class children with asthma. J Allergy Clin Immunol 2003;112:87-92.

37. Sarpong SB, Wood RA, Karrison T, Eggleston PA. Cockroach allergen (Bla g 1) in school dust. J Allergy Clin Immunol 1997;99:486-92.

38. Hill DJ, Thompson PJ, Stewart GA, Carlin JB, Nolan TM, Kemp AS, Hosking CS. The Melburne house dust mite study: eliminating house dust mites in the domestic environment. J Allergy Clin Immunol 1997;99:323-9.

39. Perfetti L, Ferrari M, Galdi E, Pozzi V, Cottica D, Grignani E, Minoia C, Moscato G. House dust mites (Dep p1, Der f 1), cat (Fel d 1 ) and cockroach (Bla g 2) allergens in indoor work-places (offices and archives). Sci Total Environ 2004;328:15-21. 


\section{Sažetak}

\section{USPOREDBA PUFERA ZA EKSTRAKCIJU ALERGENA GRINJE Der p 1 IZ PRAŠINE}

Der p 1 glavni je alergen grinje Dermatophagoides pteronyssinus koji se rutinski određuje u kućnoj prašini. Postupak ekstrakcije Der p 1 iz prašine nije dobro definiran. Cilj je ovoga rada ispitati korelaciju i slaganje između Der p 1 masenih udjela u ekstraktima prašine koji su sadržavali fosfatni $(\mathrm{pH} 7,4)$, boratni $(\mathrm{pH} 8,0)$ ili amonij-hidrogenkarbonatni ( $\mathrm{pH} \mathrm{8,0)}$ pufer s dodatkom $0,05 \%$ Tween 20. Dvadeset i osam uzoraka prašine podijeljeno je u tri skupine za ekstrakciju s jednim od tri pufera na sobnoj temperaturi. Maseni udio Der p 1 određen je u ukupno 84 ekstrakta enzim-imunokemijskom metodom (raspon: $0,1 \mu \mathrm{g} \mathrm{g}^{-1}$ do $\left.7,53 \mu \mathrm{g} \mathrm{g}^{-1}\right)$. Statističke metode, uključujući i "intraclass" korelaciju, pokazale su visoku korelaciju i slaganje između masenih udjela Der $\mathrm{p} 1 \mathrm{u}$ svim ekstraktima. Rezultati pokazuju da su sva tri pufera prikladna za ekstrakciju alergena grinje i rutinsko određivanje Der p 1 u prašini.

KLJUČNE RIJEČI: alergeni unutarnjih prostora, Dermatophagoides pteronyssinus, ekstrakcijski puferi, ELISA, "intraclass" korelacija, sedimentirana prašina

\section{CORRESPONDING AUTHOR:}

\section{Ljerka Prester}

Institute for Medical Research and Occupational Health P.O. Box 291, HR-10001 Zagreb, Croatia

E-mail:prester@imi.hr 